University of Nebraska - Lincoln

DigitalCommons@University of Nebraska - Lincoln

Agronomy \& Horticulture -- Faculty Publications

Agronomy and Horticulture Department

$5-1961$

\title{
Genetic, Developmental, and Within-Plant Variation in Free and Bound Coumarin Content of Sweetclover
}

\author{
G. W. Schaeffer \\ Brookhaven National Laboratory \\ Herman J. Gorz \\ United States Department of Agriculture \\ Francis A. Haskins \\ University of Nebraska-Lincoln, fhaskins@neb.rr.com
}

Follow this and additional works at: https://digitalcommons.unl.edu/agronomyfacpub

Part of the Plant Sciences Commons

Schaeffer, G. W.; Gorz, Herman J.; and Haskins, Francis A., "Genetic, Developmental, and Within-Plant Variation in Free and Bound Coumarin Content of Sweetclover" (1961). Agronomy \& Horticulture -- Faculty Publications. 256.

https://digitalcommons.unl.edu/agronomyfacpub/256

This Article is brought to you for free and open access by the Agronomy and Horticulture Department at DigitalCommons@University of Nebraska - Lincoln. It has been accepted for inclusion in Agronomy \& Horticulture -Faculty Publications by an authorized administrator of DigitalCommons@University of Nebraska - Lincoln. 


\title{
Genetic, Developmental, and Within-Plant Variation in Free and Bound Coumarin Content of Sweetclover ${ }^{1}$
}

\author{
G. W. Schaeffer, H. J. Gorz, and F. A. Haskins ${ }^{2}$
}

$\mathrm{D}$ ESPITE several reports of variation in coumarin content of sweetclover no comprehensive study appears to have been reported of form as well as content of coumarin at various stages in the life cycle of the plant. Determinations of seasonal variation by earlier workers were based either upon levels of free $(7,8)$ or total $(6)$ coumarin. Although these workers were not in complete agreement, in general very low levels of coumarin were observed in young seedlings, and the content increased rapidly until late summer and then decreased sharply with the approach of the end of the growing season. In second-year growth, a maximum content of total coumarin was observed at the early flowering stage followed by a rapid decrease at maturity. Brink ${ }^{3}$ and others $(2,6,7,8)$ noted that tissues of high metabolic activity, such as young leaves and buds, contained the greatest amounts of coumarin. In greenhousegrown plants, variations in genotypic combinations of the two major allelic pairs that condition content and form of coumarin were found to result in marked differences in free and bound coumarin content of young leaves $(1,3,4)$. $C u C u B B$ plants characteristically contained substantial amounts of both free and bound coumarin, $C u C u b b$ plants were high in bound coumarin but very low in free coumarin, and $c u c u B B$ and $c u c u b b$ plants were low in both forms.

In the present report, information is presented on the level and form of coumarin in various plant parts throughout the life cycle of three genetically-different classes of sweetclover.

\section{MATERIALS AND METHODS}

\section{Seeds and Seedlings}

Madrid sweetclover (Melilotus officinalis Lam.) of the $C u B$ phenotype was used for studying the level and form of coumarin in seeds and young seedlings grown in the laboratory. Fifty seeds, extracted by autoclaving in water, were utilized as samples representing seedlings of zero age. These samples, as well as 40 seedlings grown for $2,4,7$, and 14 days in 3 -inch clay pots containing vermiculite. were assayed for free and total coumarin by a modifcation of the method described by Haskins and Gorz (4). One group of seedlings was grown in the laboratory under a bank of standard cool white fluorescent lamps. The intensity of light at the surface of the table upon which the pots rested was approximately 850-900 foot-candles. Another group of seedlings was yrown in complete darkness. The final assay of these seedlings was made after a growing period of only 12 days because of the rapid deterioration of the seedlings at that age. The temperature wals

'Cooperative investigations of the Crops Research Division, ARS, ISDA, and the Nebraska Agr. Exp. Sta., Lincoln, Nebr. Published with the approval of the Director as Paper No. 1054, Journal series, Nebraska Agr. Exp. Sta. Data were taken from a thesis submitted by the senior author in partial fulfillment of the requirements for the Ph.D. degree. Received Sept. 6. 1960.

${ }^{3}$ Formerly graduate student in Agronomy, University of Nebraska, now at Brookhaven National Iaboratory, Upton, N. Y.; Geneticist. Crops Research Division. ARS, USDA; and Professor of Agronony. University of Nebraska, respectively.

${ }^{3}$ Brink, V. C. The content, distribution, and some metabolic aspects of Coumarin in sweetclover (Melilotus alba Desr.). ['npublished Ph.D. Thesis. L'niversity of Wisconsin. 19 f́1. approximately $25^{\circ} \mathrm{C}$. under the lights and $24^{\circ}$ in the dark. Seedlings were watered daily with tap water except for saturation of the vermiculite containing the light-grown seedlings with Hoagland and Arnon's (5) nutrient solution No. 1, supplemented with micro-nutrients, at 5,8,10, and 12 days after planting.

Material which inhibited the development of fluorescence and, therefore, interfered with assays of free coumarin was encountered in extracts of seeds and seedlings. Free coumarin, however, could be effectively separated from the inhibitory substance(s) by three extractions with ether. Ether extracts containing the free coumarin were evaporated to near-dryness, diluted to the original volume with water, and assayed in the usual manner. The inhibitory substance(s), apparently destroyed by autoclaving in alkali, did not interfere with deterninations of total coumarin content.

\section{Field-grown Plants}

Sweetclover ( $M$. alba Dest.) plants of three different phenotypes were used. Phenotype $C u B$ was represented by the variety Evergreen and phenotypes $C u b$ and $c u$-by Wisconsin experimental synthetics W-7 and $W^{\prime}-31$, respectively. Seeds were planted in 25 -foot rows spaced 3 feet apart in adjacent plots in the field in 1958 and 1959.

Assays of both first-and second-year plants were made in 1959. Samples were collected at 2-week intervals until the second-year plants had reached maturity; thereafter, only first-year plants were
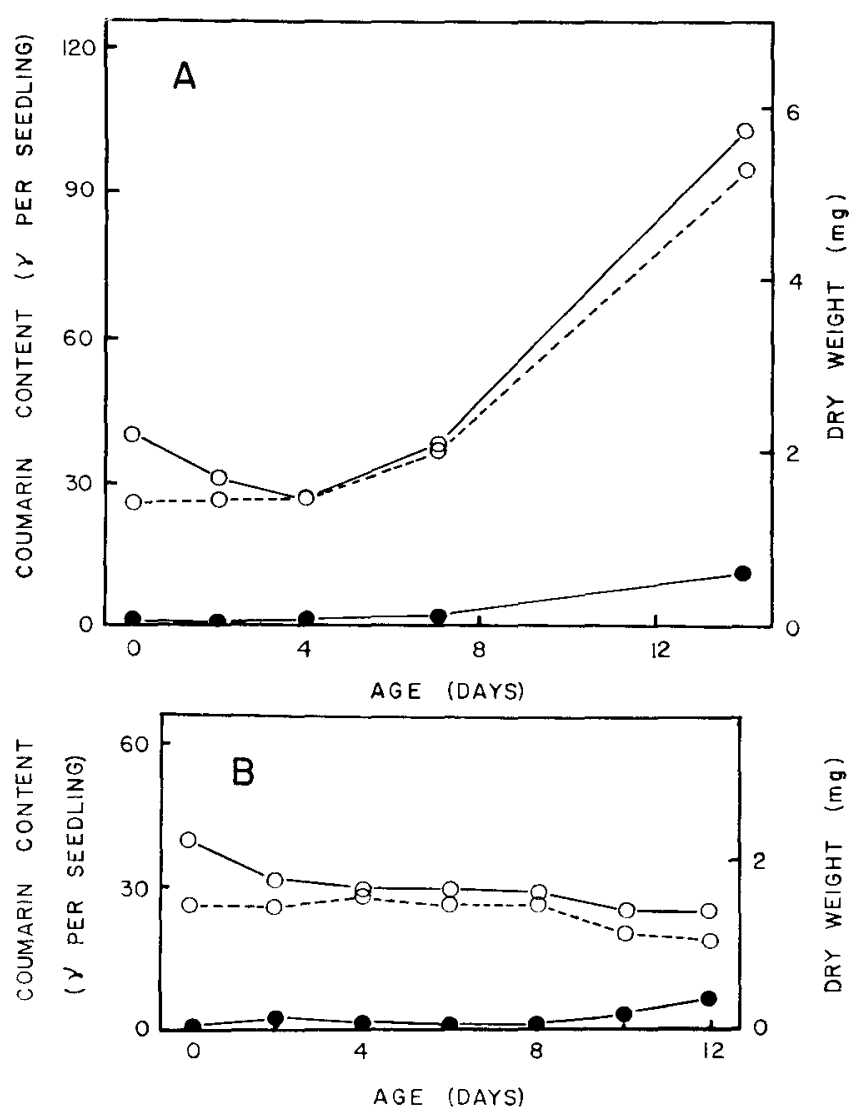

Figure 1-Dry weight and coumarin content per seed or seedling of Madrid sweetclover grown under (A) fuorescent lights and $(B)$ in darkness. Dry weight $0-0$, total coumarin, $o_{---o}$, free coumarin $\bullet-\bullet$. 
assayed and samples were taken at 4 -week intervals. At each sampling date, 4 randomly selected, healthy-appearing plants from each of the 3 phenotypes were removed from the soil to a depth of 12 inches and transported to the laboratory in a box whose interior was kept cool and moist by means of cold water and ice cubes.

The mid-leaflet from the youngest fully expanded leaf at the tip of a dominant central branch was taken as the leaf sample. Stem samples consisted of 1 -inch sections of stem removed at a distance of 3 inches from the tip of the central branch that had provided the leaf sample. After the roots had been washed with tap water and dried with paper towels, a small sample of root tissue was removed from the tap root 6 inches below the crown. Fresh weights of the samples to be assayed were obtained rapidly with a direct-reading, single-pan balance, and the samples were then autoclaved in water. Following removal from the autoclave, the samples were cooled and mixed and the plant tissue was discarded before the extracts were stored in a freezer for later assay. Determinations of dry matter were based upon fresh and dry weights of samples oven-dried for 6 to 8 hours at $100^{\circ} \mathrm{C}$. The dry-matter samples were similar in size and position on the plant to the samples used for extraction.

The water extracts were assayed for free and total coumarin by the fluorometric method described by Haskins and Gorz (4). Bound coumarin was determined by calculating the difference between the total and free coumarin contents of each sample Results from the individual assay of four similat plants harvested on the same date were averaged except for the iu-phenotype in which an occasional plant resulting from apparent outcrossing to high countarin sweetclover had to be discarded.

\section{RESULTS AND DISCUSSION}

Assay of Seeds and Seedlings

The contents of free and total coumarin in seeds of Madrid sweetclover and of Madrid seedlings grown in the

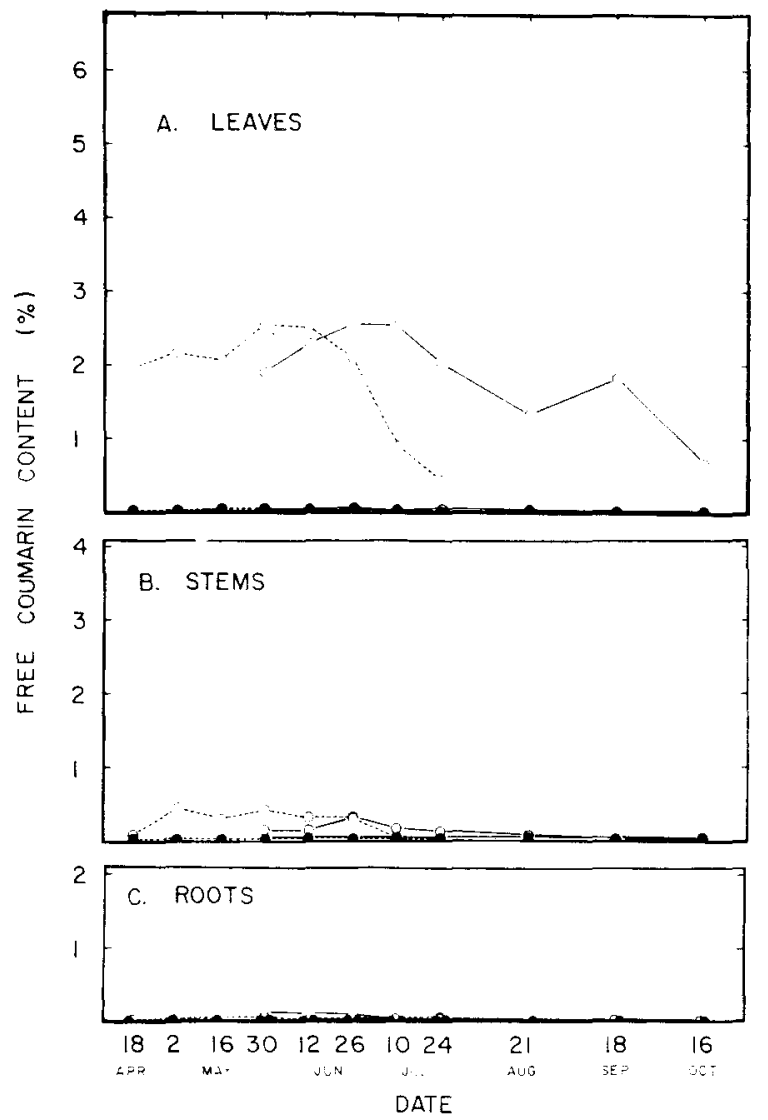

light and in complete darkness are illustrated in Figure 1. The level of free coumarin was very low in seeds and young seedlings, although in light-grown seedlings free coumarin content increased as the plants grew. In the dark, the level of free coumarin remained relatively constant until the seedlings began to deteriorate 10 to 12 days after planting. Total coumarin content increased rapidly with age in the light-grown seedlings, but remained constant in those grown in the dark. In both types of seedling, decreases in dry weight during the first 4 days were not accompanied by decreases in total coumarin content. Apparently, coumarin does not serve as a readily available carbon source in the metabolism of young sweetclover seedlings.

\section{Level and Form of Coumarin in Field-grown Plants}

The free and bound coumarin contents of leaves, stems, and roots of first- and second-year sweetclover plants of three phenotypes sampled periodically throughout the 1959 growing season are presented in Figure 2. The free coumarin content of leaves of first-and second-year plants of the $C u B$ and $C u b$ phenotypes are presented in Figure $2 \mathrm{~A}$. The large difference in free coumarin content of the two phenotypes throughout the growing season is due to a genetic difference with respect to the $B / b$ allele, which governs the synthesis of free coumarin. The maximum level of free coumarin in $C u b$ leaves was approximately $0.05 \%$, whereas the maximum content in $C a B$. occurring in early July and late May in first-and second-year growth, respectively, was approximately $2.50 \%$. The level of free cou-

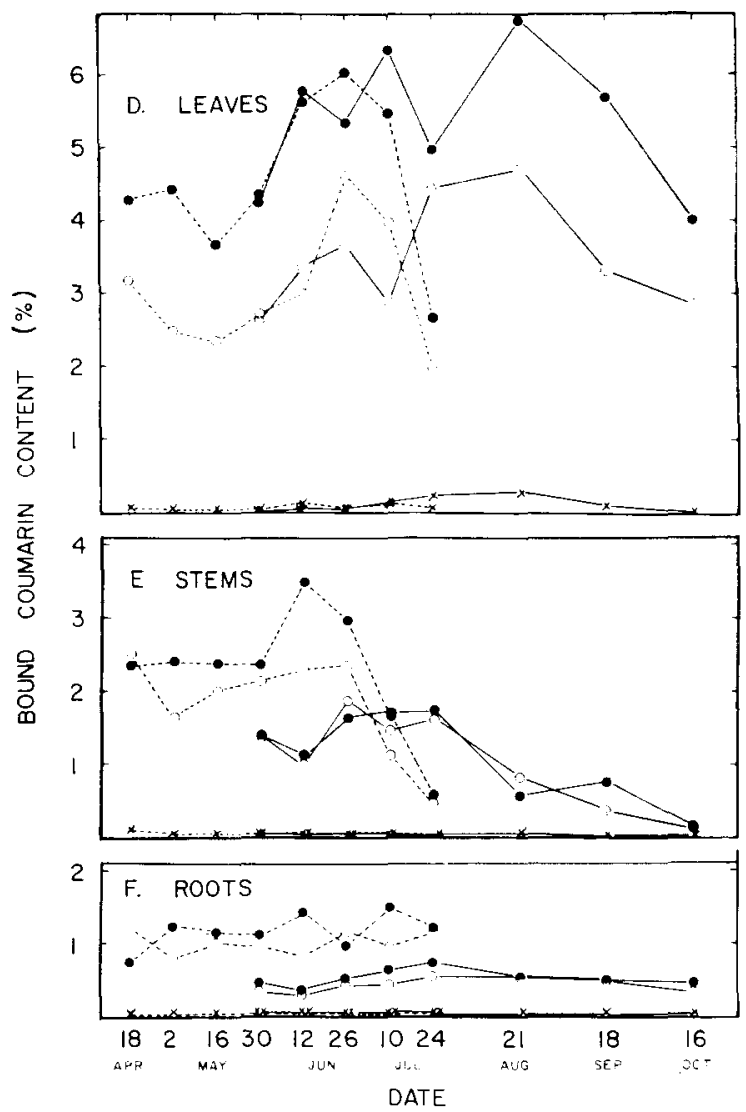

Figure 2-Free (A, B, C) and bound (D, E, F) coumarin in tissues from three phenotypes of sweet clover sampled periodically throughout the life cycle. Symbols: $C u B$ (Evergreen)-first year o- 0 , second year $0--0 ; C u b(W-7)-$ first year $\bullet-\bullet$, second year $\bullet-\ldots$; $c u-\left(W^{-31)}\right.$-first year $\mathrm{x}-\mathrm{x}$, second year $\mathrm{x}-\mathrm{x}_{-\mathrm{x}}$. 
Table 1-Average levels of free and bound coumarin in leaves, stems, and roots of the $C u B$ (Evergreen), $C u b$ (W-7), and cu- (W-31) phenotypes of sweetclover in the second year of growth. Data are based on samples taken May 30, June 12, and June 26, 1959.

\begin{tabular}{|c|c|c|c|c|}
\hline \multicolumn{2}{|c|}{$\begin{array}{l}\text { Type of tissue and } \\
\text { ferm of coumarin }\end{array}$} & \multicolumn{3}{|c|}{$\begin{array}{l}\text { Coumarin bercentage (dry wt, hasis) } \\
\text { for plants of indicated phenotype }\end{array}$} \\
\hline & & $\underline{\mathrm{C}} \underline{\underline{B}}$ & Cub & (4). \\
\hline Leaves: & $\begin{array}{l}\text { Free } \\
\text { Bound }\end{array}$ & $\begin{array}{l}\text { Mean }+ \text { S. E. } \\
2.38+11.093 \\
3.44+0.290\end{array}$ & $\begin{array}{l}\text { Mean } \pm \text { S. E. } \\
0.05 \pm 0.004 \\
.5 .35+0.240\end{array}$ & $\begin{array}{l}\text { Meant S. E. } \\
0.10+0.018 \\
0.08+0.027\end{array}$ \\
\hline Stems: & $\begin{array}{l}\text { Free } \\
\text { Bound }\end{array}$ & $\begin{array}{l}0.35 \pm 0.025 \\
2.28 \pm 0.141\end{array}$ & $\begin{array}{l}0.02 \pm 0.0033 \\
2.34 \div 0.1 .70\end{array}$ & $\begin{array}{l}0.01 \div 0.001 \\
0.04 \div 0.005\end{array}$ \\
\hline Roots: & $\begin{array}{l}\text { Free: } \\
\text { Bound }\end{array}$ & $\begin{array}{l}0.05+0.008 \\
0.98+0.0982\end{array}$ & $\begin{array}{l}0.02 \pm 0.003 \\
1.11 \pm 0.118\end{array}$ & $\begin{array}{l}0.01 \div 0.002 \\
0.01: 0.002\end{array}$ \\
\hline
\end{tabular}

marin in $C u B$ leaves decreased with the approach of fall in the first year and with the maturation of the plants in the second year. Figure $2 \mathrm{~B}$ illustrates the free coumarin content of stems. The $C u B$ phenotype was again higher than $C u b$, with a maximum of approximately $0.5 \%$. As in leaves, the content of free coumarin in stems declined with the approach of autumn and with the maturation of the plants. Root tissue was low in free coumarin at every sampling date (Figure 2C). Since the level of free coumarin was very low in all tissues of the cu-phenotype throughout the season, data from this phenotype were not included in Figures 2A, B, and $\mathrm{C}$.

The levels of bound coumarin in leaves from plants representing the three phenotypes are shown in Figure $2 \mathrm{D}$. The relatively high levels in the $C u B$ and $C u b$ phenotypes were in sharp contrast to the low level in cu-Although the bound coumarin content of $C u b$ leaves exceeded that of $C$ HB , the total coumarin contents of the two phenotypes were similar, varying from 4 to $6 \%$. Maximum levels of bound coumarin in the $C u B$ and $C u b$ phenotypes were observed during the third week of August in the first year and in late June in the second year. Bound coumarin levels in the two phenotypes, like free coumarin levels in the $C u B$ phenotype, fell sharply in the fall in first-year material and with maturation of the plants in second-year material. Figures $2 \mathrm{E}$ and $2 \mathrm{~F}$ show the bound coumarin contents of stems and roots, respectively. The level of bound coumarin in stems was appreciably lower than that found in leaves, but exceeded that found in roots. Bound coumarin level in roots did not drop appreciably at the end of the first season of growth or at the time the plants matured in the second year.

The three consecutive sampling dates with the highest levels of free coumarin in the second year were May 30 , June 12 , and June 26,1959 . Data from these three sampling dates were averaged for presentation in Table 1 in order to show maximum contents of coumarin for each phenotype and the influence of the $c u$ and $b$ genes on level and form of coumarin in several types of tissue. The means and standard errors given in Table 1 represent 12 individual determinations for the $C u B$ and $C u b$ phenotypes and 10 for $c u$. The data presented show clearly the influence of the $c u$ and $b$ genes on level and form of coumarin in sweetclover. Leaves of the $c u$ - phenotype had less than $1 / 25$ as much total coumarin as leaves of the $C u$-phenotype. The free coumarin content of leaves of the $C u B$ phenotype was approximately 45 times that of the $C u b$ phenotype. Nearly $41 \%$, of the total coumarin in $C u B$ plants was in the free form contrasted with only $0.93 \%$ in $C u b$ plants. Stems and roots had approximately one-halt and one-fifth as much total coumarin, respectively, as leaves. It may be concluded, therefore, that level and form of coumarin in sweetclover are strongly influenced by genetic and developmental factors and by the portion of plant sampled.

\section{SUMMARY}

Seeds of sweetclover contained a low level of both free and bound coumarin. An increase in both forms of coumarin occurred when seedlings were grown in the light, but no increase was found when they were kept in the dark. First- and second-year plants of Evergreen ( $C u B$ phenotype), W-7 (Cub), and W-31 (cu-) were sampled in the field at intervals throughout the 1959 growing scason. Leaves, stems, and roots were assayed for free and total coumarin content. The level of free coumarin was highest in the leaves of plants of the $C u B$ phenotype, with a small amount in stems and virtually none in roots. Bound coumarin was found in appreciable quantities in leaves, stems, and roots of $C u B$ and $C u b$ plants, although leaves had an appreciably higher level than stems, and stems contained a higher percentage than roots. The low content of free and bound coumarin in roots tended to remain constant throughout the season, whereas in leaves and stems a sharp drop in both forms was noted toward the end of the first season of growth and as the plants approached maturity in the second year. Plants of the cu-phenotype were low in both forms of coumarin throughout the entire life cycle.

\section{LITERATURE CITED}

1. Goplin, B. P. Grennshierds, J. E. R., and Bafnziger, H The inheritance of coumarin in sweet clover. Can. J. Bot. 35 : $583-593.1957$.

2. —__ and White, W. J. Selection techniques in screening for coumarin-deficient sweet clover plants. Can. J. Bot. 34:711-719. 1956.

3. Gorz, H. J., and Haskins, F. A. Genetic blocks in the synthesis of coumatin in Melilotws albu. J. of Hered. $51: 71-76$. 1960 .

4. HASkINS, F. A., and GoRz, H. J. Fluoronetric assay of free and bound coumarin in sweetclover. Agron. J. 49:193-197. 1957.

5. HoAgl.AND, D. R., and ARNon, D. I. The water-culture method for growing plants without soil. Calif. Agr. Exp. Sta. Circ. 347. i2 Pp. Revised 1950.

6. Slatensek, J. M. Some causes for variation of coumatin content in sweetclover. J. Am. Soc. Agron. 39:596-605. 1947.

7. STrvenson. T. M., and Clayton, J. S. Investigations relative to the breeding of coumarin-free sweet clover, Melilotus. Can. J. Res., C. 14:153-165. 1936.

8. WhITE, W. J., and HorNer, W. H. Investigations concerning the coumatin content of sweet clover. II. Sources of variation in tests for coumarin content. Sci. Agr. 21:29-35. 1910.

\section{Addendum}

Work done by the second and third authors subsequent to the submission of this manuscript indicates that intact sweetclover plants contain little if any free coumarin. Details of this work will be presented in a future paper. The free coumarin values given in the present paper provide an indication of the magnitude of enzymatic hydrolysis of bound coumarin during the extraction procedure, but the accuracy with which these values reflect levels of free coumarin in the plant is now in doubt. Levels of total coumarin may be calculated by adding values for the free and bound forms given in this paper. These total coumarin levels are not invalidated in any way by the recent findings regarding free coumarin. 